\title{
Effect of Easy Transaction, Consumer Interests, and Systems Security Level Measures against Fraud Online Shopping in Lazada
}

\author{
Meiliyah Ariani ${ }^{1}$ and Zulhawati ${ }^{2}$ \\ ${ }^{1}$ Faculty of Economics, Universitas Prof. Dr. Moestopo (Beragama) \\ Jakarta, Indonesia \\ ${ }^{1}$ Faculty of Information Technology and Business \\ Universitas Teknologi Yogyakarta \\ ${ }^{1}$ meiliyah_ariani@dsn.moestopo.ac.id, ${ }^{2}$ zulhawati@gmail.com
}

\begin{abstract}
This study aimed to examine the effect of the ease of the transaction, the consumer interest, and the level of system security against acts of fraud on online shopping. Ease of transaction is measured from the transaction speed, high accuracy, high volume transaction, highly correlated, and ease of access are high. Measurement of consumer interests is including motivation, perception, learning, and memory. System security level measured from the privacy, integrity, autentication, availability, and access control.Sample selection is done by using purposive sampling method. The research data were collected from students of the Faculty of Economics, University of Trisakti. The samples used were 100 accounting students from semesters 1 to 9. The analysis technique used is multiple regression in SPSS version 23. The results showed that the factors such as the ease of transactions, consumer interest, and the security level of the system is partially measured by the transaction speed, high accuracy, high volume transaction are highly correlated. Meanwhile, ease of access is high, motivation, perception, learning and memory does not have a significant effect on the action of cheating but the privacy, integrity, autentication, availability. The access control can influence the actions of fraud significantly. Influence ease of transactions, consumer interest, and the security level of positive and significant impact on fraud actions simultaneously.
\end{abstract}

Keywords: Ease of transaction; Consumer interests; Level security systems; Action fraud.

\section{Introduction}

Growing and developing communication technologies make a variety of influences for its users. It has two views of communication technologies in terms of positive and negative aspects so that people are required to be able to take advantage of the technology according to their function. Internet is a form of technological development which has now become a necessity for most people because of the changing times require knowledge of technology can be used and utilized by all parties. Modern technological developments have implications on the performance changes for human life and technology becomes a winner and a rapidly growing technology is to serve and accommodate the entire human not just the advanced technology that was created for sophistication itself [1]. One of the technologies is internet technology that originated from research to defense and security and education, has now developed into a business support tool that is very influential. Advances in technology and the high interest for information, make knowledge of Internet technology is extensive developed. Such as communicating to find out about the qualifications of a particular brand and provide online information to help consumers better understand the products or services that are 
intangible interest [2]. Knowledge of the internet will affect the trust and expectations of the results obtained on the usage of the computer for work and using a personal computer. Using knowledge of internet technology, consumer confidence will increase and can be easily in the use of Internet applications [3]. The Internet is a relationship between different types of computers and networks in the world that has an operating system and different applications. The relationship is utilizing advances in communication devices such as phones and satellites that use a standard protocol in the relationship of communication, i.e. TCP or IP (Tranmission Control or Internet Protocol) [4]. While the understanding of the different Internet is a computer network that is currently growing rapidly from a wide range of business interests, education, up to the government network. Interconnected to one another, where the number of users can grow in excess of 200 countries [5]. From the definition above shows that the internet is a network that is most often seen as a center of development of information. Internet works by connecting all of the computers in the world into one network to communicate with each other in the relationship between network. Internet requires a protocol in order to receive and send information i.e. TCP or IP. It can be deduced that the Internet is a large network of interconnected to one another across the country were able to communicate by exchanging information or other information as required by its users has been available for complex.

Nowday, internet users take advantage of a variety of activities in a fast, easy and convenient as buying and selling online advertisements that generate revenue quickly and do not have to work too hard. Such as buying or selling clothes, toys, shoes, computers, cosmetics, until the jewelry can be distributed online via the internet. The establishment of online stores, sellers and buyers can conduct transactions without having to meet face to face. This will make the transaction faster and easier to shop online has advantages and disadvantages of each. In Indonesia itself has many founding online shopping sites are increasingly popular and well known by the public. As we can see that online shopping already started to become a common activity for the people of Indonesia, the trend will continue to increase from year to year that can meet all the needs of society as quickly. Here are some sites online store or online shop renowned as Lazada, Tokopedia, Kaskus, Bhineka, Zalora and berniaga are present as a provider of all your online necessity (See Figure 1).

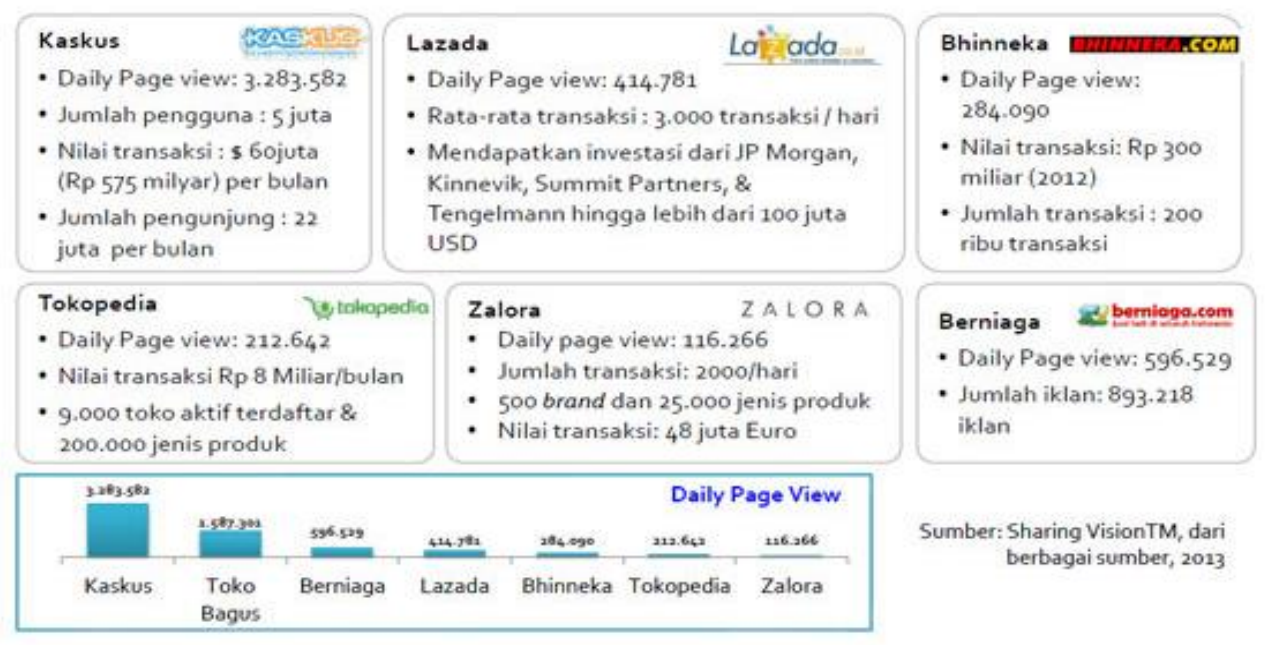

Figure 1. Providers of e-Commerce in Indonesia

There are several information systems that encourage smooth all existing activities on online shopping ranging web appearances from sales, ordering, to payment, all has been well-organized. Information system itself is a system that is organized in a way to collect, 
enter, process and store organized data to store, manage, control and report information accurately within an organization in order to achieve the goal that has been set [6]. The online companies need to have information system more effective and efficient, to be more accurate, reliable, and more up to date so that users find the latest information provided and are fast to serve in case of dissatisfaction buyers.

Lazada is one place to shop online, which is commonly known as one of the online shop largest online trading center in Indonesia. The advantages of Lazada, (1) the web interface is not difficult because of the displayed attractively; (2) the navigation is clear and understandable enough guidance so that consumers will not be lost in the website Lazada; (3) display featured products that allow consumers to find the goods sold and recommended; (4) sells a wide range of available products to find new items or used items such as product quality mobile phones, computers, fashion, health, beauty, automotive, and other equipment; (5) paid on the spot and it offers many attractive discounts. Their great discount makes web Lazada always visited by more than hundreds of thousands every day; (6) transact in Lazada, whether sale or purchase is not charged, all provided free of charge. Lazada is a third party which the seller may entrust his wares with images that have been given a description or information in accordance with a product that makes it easy for prospective customers. Shopping online is more interesting because you no longer have to leave the comfort of home to go to the store to buy a favorite brand of clothing or even go to the store to shop thus wasting time and energy over long distances to go to the store. Besides, free from aggressive salesman trying to force the purchase of goods offered, while shopping at the online store only consumers and the desired goods from web catalogs that have been available. In addition to the advantages of online shopping sites also have weaknesses that can be used as a reference to be more vigilant in choosing the online shopping sites are accurate and reliable. Weaknesses can be described as follows: (1) items purchased through online stores usually do not directly reach the hands of customers having to wait for their delivery process; (2) buyers also tend to feel worried if the process of advance payments; (3) information about the product only of text and images were usually only put text (explanation) and the images alone or sometimes in the form of animation.

Based on the description above, not all online shopping sites can have a positive effect, but not the least there are cases of fraud or scams often occur. examples of cases that occurred in online shopping in Lazada i.e:

a. Fraud at the time the payment confirmation.

b. Delayed payment orders for goods already done turns "sold out" and decline the receiving or unclear arrival of goods will be accepted.

c. Carelessness or negligence in checking supply, so the inventory displayed on the Web does not comply with the request.

d. Refunds are difficult to be processed.

e. Discount vouchers are often considered to have been used. Though it has not been used vouchers, voucher obtained an email sent directly to email customer Lazada.

f. The ordered goods are not in accordance with accepted.

g. Goods that have been paid and the confirmation that the goods will be sent but rejected or not be sent.

h. Ordered goods in many quantity are just received one item only.

i. Poor customer service to the customer for rendered services on the Lazada not as expected.

j. Specifications or quality of the goods do not match with the sale of goods on offer and guarantee 14 days refunds are not addressed if there are problems.

k. Unreasonable discounts product.

Here are a few cases of fraud or deception of the product undertaken by lazada online stores: 
a. Booking Asus Zenfone 6 does not come, who received just two boxes of clothing deodorizer Kispray and iPhone 6 Plus orders received soap bars with brand Nuvo.

b. Specifications or quality of the goods do not match with the sale of goods on offer and guarantee 14 days refunds are not addressed if there are problems.

c. Unreasonable discounts product

d. Statement of consumer complaints from online shopping lazada

Firman [7] has a conclusion in his research is able to attract more new customers to increase the motivation of online shopping, because the concept of e-commerce or electronic commerce via the Internet has become the center of attention of many people who provide convenient shopping system. According to Suhartini [8], she has a conclusion in her research that the site's security, accessibility and design professionals, if the manufacturer does not improve the quality of the website so prospective consumers are not interested in the quality of the website are displayed for not getting the needed information by consumers. Based on the description of the background research, this problem can be formulated: Are there influences the ease of transactions, consumer interest, and the security level of the system partially or simultaneously against acts of fraud on shopping online.

The goal to be achieved in this study is to examine and obtain empirical evidence of the influence of the ease of the transaction, the consumer interest and the security level of the system partially or simultaneously to act on online shopping fraud.

The rest of this paper is organized as follow: Section 2 describes related works. Section 3 describes material and proposed method. Section 4 presents results and following by discussion. Finally, the conclusion of this work is described in Section 5.

\section{Literature Review}

\subsection{Online Shopping}

Literally Internet or global system-networking interconnection of the entire network of computers are connected together using the standard Internet Protocol Suite (TCP or IP) to serve billions of users worldwide. The advent of the Internet provides convenience to many people in an activity, searching for information, even in business. In the world of Internet business can be used as a medium to market a product or marketing, and besides the Internet can also be used to make buying and selling. In the process of buying and selling with the Internet, people no longer need to leave the house to shop, supermarket, or the market. We quite easily access the Internet using a computer device that is virtually owned by many people today. Selecting and ordering items to be purchased, and make buying and selling via the Internet is called an E-commerce or shopping online [9]. Here are some strong arguments about many people prefer to shop online:

a. Time

Flexible time is a factor that is quite interesting, attention to shopping online. Because transactions can be done anytime and anywhere as long as we have access to the internet. And usually when we make a purchase online we do not take a long time. We just simply buy items from the display that has been provided on the website or online store sites after the transaction. So the purchasing process to be faster because we will be more focused in selecting goods than we are physically shopping around the mall without a clear purpose.

b. Price

The price offered in some online stores is cheaper than we buy physical goods or offline. Even the price offered can be cheaper twice the price of goods sold offline.

c. Availability of goods

When we buy goods physically go to the store then we will be faced with the limitations of the number and type of diversity of goods. Not all items are available in 
a physical store, while if we look for goods via the internet we can get almost all the things we want because the Internet is not limited by place. Many online stores are located physically outside Jakarta or outside the city or all over Indonesia and have a diversity of goods and services with the Internet we can do online shopping at the online store without thinking about the place and time limits.

Online shopping is the process whereby consumers directly buy goods or services from sellers in real-time without an intermediary service. In recent years, online shopping has become popular but still serves the consumer the upper middle. A system like this does have a lot of convenience but not a few risks that could arise. The risks include undelivered goods, e-mail address is sold to another party, or theft of personal data buyers. Personal data are vulnerable to abuse, one of which is a bank account, either a savings or credit cards and others. Here are some advantages and disadvantages of shopping online:

a. Advantages of shopping online

- Buyers do not need to visit the point of sale, be it shops, boutiques, malls, etc. Buyers simply click to web destination and select the desired items.

- Selection of items can be done from home or office so that the purchase can be made for hours without having to leave home.

- The seller can reduce the cost of opening a store because through shopping online, sellers enough to market their products via the Internet.

b. Disadvantages of Shopping Online

- The quality of the desired goods sometimes different quality to the ones listed on the website.

- Vulnerable scams where many cases when the buyer has sent a sum of money agreed upon, the purchased goods are not delivered.

- Vulnerable damaged or broken due to media and postal delivery.

- Vulnerable piercing action account, because the payments are made through the Internet.

- Lots of spamming action because after buyer registration, sellers tend to always send the online catalog via email buyer and it is quite disturbing privacy.

\subsection{Electronic Commerce}

Electronic commerce (e-commerce) is buying and selling, marketing and service of products, services, and information via computer networks [10]. Many companies are now engaging in or sponsoring three basic categories of e-commerce applications: $e$ commerce business-to-consumer, business-to-business, dan consumer-to-consumer [11]. E-commerce has two sides of different perspectives for entrepreneurs. On the one hand, they can reach consumers without limited by geographical location. But on the other hand they become increasing competition not only from shops around them but from stores around the area. And, when consumers get the products directly from the factory or from the grocery store, the intermediaries will be eliminated. According to Solomon [12], some of the advantages and limitations of e-commerce are given in Table 1 as following:

\section{Table 1: the advantages and limitations of e-commerce}

\begin{tabular}{|c|c|c|}
\hline & The advantages of e-commerce & The limitations of e-commerce \\
\hline For consumers & $\begin{array}{l}>\text { Shop } 24 \text { hours a day without } \\
\text { traveling. } \\
>\text { Can receive relevant information } \\
\text { quickly without limited by location. } \\
>\text { More choice of products. } \\
>\text { More products are available for less } \\
\text { developed countries. }\end{array}$ & $\begin{array}{l}\text { lack of security. } \\
\text { Fraud. } \\
\text { Can not touch the product. } \\
\text { Similar colors may not be displayed } \\
\text { clearly on the screen computer monitor. } \\
\text { The high price for the booking and refund } \\
\text { if there is a mismatch }\end{array}$ \\
\hline
\end{tabular}




\begin{tabular}{|c|c|c|}
\hline & $\begin{array}{l}>\text { More pricing information. } \\
>\text { Lowering the price so that it can } \\
\text { reach consumers from all walks of } \\
\text { economy. } \\
>\text { Participate in virtual auctions. } \\
>\text { Prompt delivery. } \\
>\text { online community. }\end{array}$ & $\begin{array}{l}\text { Potentially damaging relationships with } \\
\text { others. }\end{array}$ \\
\hline for Manufacturers & $\begin{array}{l}>\text { The world is the market share. } \\
>\text { Reducing the cost of doing business. } \\
>\text { Highly specialized business can be } \\
\text { successful. } \\
>\text { Prices in real-time. }\end{array}$ & $\begin{array}{l}>\text { lack of security. } \\
\text { Must manage the site to get the results. } \\
>\text { Intense price competition. } \\
>\text { Conflict with conventional sellers. } \\
>\text { Legality issues unresolved. }\end{array}$ \\
\hline
\end{tabular}

Based on the above table, on the side of the consumer benefits, it is known that by using e-commerce consumers can make purchases more freely, especially in selecting and comparing goods or services to be purchased between multiple vendors. Thus, the buyer will acquire goods or services are appropriate, both price and features. The advantage of the entrepreneur or businessperson with implementing e-commerce, the cost of doing business can be reduced and market share much wider. While on the limitations of many consumer concerns on the security aspects, knowledge of the buyer, and the products can not be tried first. Therefore, in line with the development of e-commerce security technology, the amount of information and the user community of e-commerce, as well as the increasing availability of Internet infrastructure, then the losses faced shoppers can increasingly be reduced. Limitations of e-commerce for entrepreneurs are the very tight competition and the lack of regulations regarding the legality standard regulations in conducting transactions online.

\subsection{Easy Transactions}

Perceived ease of use is defined by Davis in [13] and Chin and Todd [14] is how much perceived computer technology is relatively easy to understand and use. This convenience factor associated with how operations transact online. According to Mulyadi [15], information technology is the ability to make business transactions that can not be imagined into reality, even capable of putting the company several steps ahead of pesaing. Adams, et al. [16] states that the intensity of use and interaction between user and the system can also show the ease of use. The system is often used to denote that the technology is better known, is easier to operate, and easier to use by the user. If consumers perceive a product easy to use, they will feel the usefulness of the product to meet their needs and desires [13]. Igbraria [17] stated that the perceptions of individuals with regard to the ease of using a computer is the degree to which an individual believes that using a particular system would be free of errors. This perception then will have an impact on behavior, i.e. the higher one's perception of using a system, the higher the level of utilization of information technology. So the ease of use of technology will increasingly be used by prospective customers to access the site tokopedia.com.

Technology Acceptance Model or TAM) is a model of acceptance of information technology systems will be used by the user. Perceived ease of use is defined as the extent to which a person believes that using a technology would be free of effort. Perceived ease of use is an assertion about the decision-making process. If someone believes that the information system is easy to use then he/she would use. Conversely, if a person feel confident that the information system is not easy to use then he/she will not use [18]. Information technology can be viewed from two angles, namely the standpoint of deductive and inductive. Deductive view of information technology is starting with the formulation of the problem through the use of the ability of the information technology. By deductive view, information technology is seen only as a technology that can be used 
to solve a problem known earlier. for example, in transaction sales service hotels, because of often the room at the time of going to check out, then the computer used to process transactions with living (eating, and drinking, telephone, mini bar and room rental), so that the computer can solve the problem of slow service the guests who will check out.

Inductive view of information technology is starting with exploring various potential capabilities contained in the information technology, then carried out a search of various opportunities that can be achieved by using the potential capabilities. Then, it is regarded as a problem after a promising information technology solution to the problem. For example, before the telecommunications and computer with internet networking company offering solutions for employees who work part-time, people thought that the employees who work full time and can not follow further education is not an issue. So it becomes a problem because of the inability of the employees will be the development of more complex technology make it responsive to the changing demands of the business environment.

Deductive thinking which saw the problem first and then find solutions to information technology, while thinking inductively starts with realizing the advantages that are stored in the information technology to offer problem solving. The impact of technological advances combined with the digital computer and communication technology or optical laser technology to make business have a new platform (digital platform) that has the following characteristics [15]:

a. Speed of Light

Business transactions at the speed of light (light speed clock) impact on competition base expansion. Previous base competition based on price, and extends to the marketing base and base quality. Then added with a time base (time based competition).

b. High Accuracy

Business transactions with high accuracy impact on business management based on the fact (fact-based business). Digital technology resulted in increased competition in the accuracy and reliability of service. There was also an increase in learning ability, suppress errors (lowering error) and the search for scapegoats (finger pointing).

c. High Volume Transaction

Tremendous impact on improving productivity, which is no longer limited volume of transactions physically. As transactions occur in the financial sector held by overbooking (over booking) by Digicash with very large transaction volumes at high speeds, which will not be done physically.

d. Highly Correlated

Transactions are conducted online, real-time, simultaneous, continuous and global. Such connectedness result in unison throughout the world so that competition is global, that there is no room for local businesses who simply restrict their transactions to the local scope.

e. Ease of Acces is High

Ease of access is high that makes business is virtual. The presence of goods, services, and organizations physically do not matter any more because of a physical thing can be enjoyed or accessed virtually. This condition is commonly referred to as virtual reality something that becomes as real despite the fact that the virtual. Examples of virtual reality is the use of computers to shop with the e-shopping facility. Physically senses of sight and sense of hearing we are faced with the reality of the goods offered, but outside the actual monitor that offer virtual. Virtual reality has made a transaction which had been in the market place (the physical location of a meeting place for buyers and sellers) to a deal in the market space (the location of the virtual meeting place for buyers and sellers). 


\subsection{Consumer Interest}

Kotler [19] stated that consumer interest can be attributed to consumer behavior in which an individual, groups, and organizations select, purchase, use, and how goods and services, ideas, or experiences to satisfy their needs and desires. Consumer behavior is influenced by several factors, among others:

a. Cultural Factors

Culture is a basic determinant of a person's desires and behavior. Each culture consists of several smaller sub cultures that provide identification and socialization that are more specific to their members. Sub culture includes nationalities, religions, racial groups and geographic regions. Thus, in each individual experiencing social stratification, in the form of social class, division relatively homogenous and have members who share their values, interests, and the same behavior.

b. Social Factors

Someone Reference Group is a group that has a direct effect (face to face) or indirectly on the attitudes or behavior of the person. The family is the most consumer purchasing organization in the community, and family members presented the main reference group of the most influential. Role consists of the activities expected to be carried out by someone with the status of each role.

c. Personal Factors

Purchasing decisions are also influenced by personal characteristics. Personal factors include age and stage in the life cycle of the buyer because they relate to individual tastes - each individual; jobs and economic circumstances affect the consumption patterns; personality is a set of human psychological trait that causes relatively consistent response and durable to environmental stimuli (including purchasing behavior) and self-concept; as well as the lifestyle is the lifestyle of a person in the world that is reflected in the activities, interests, and opinions that describing someone as a whole with its environment and core values also affected due to a deeper than in the behavior or attitudes and choices and desires someone on the ground level in the long term.

d. Internal Factors of Consumer

- Motivation

The need becomes a motive when it needs to rise to the level of intensity that is enough to encourage someone to act.

- Perception

The process whereby select, organize, and interpret input information to create a picture of the world.

- learning

Encourage changes in individual behavior that arises from experience. Learning is produced through the interaction of encouragement, stimulation, sign, response, and reinforcement.

- Memory

Short term memory - STM temporary and limited information storage and long-term memory - LTM more permanent storage and essentially unlimited so that it includes all the thoughts, feelings, perceptions, images, experiences, beliefs, attitudes, and so on products or services. The decision to purchase is made by the buyer is actually a collection of a number of decisions. In the decision process, the stages through which the online buyer is the recognition of the need, information search, evaluation of alternatives, purchase decision and behavior after purchase.

The decision to purchase made by the buyer is actually a collection of a number of decisions. In the decision process, the stages through which the online buyer is the recognition of the need, information search, evaluation of alternatives, purchase decision and behavior after purchase. 


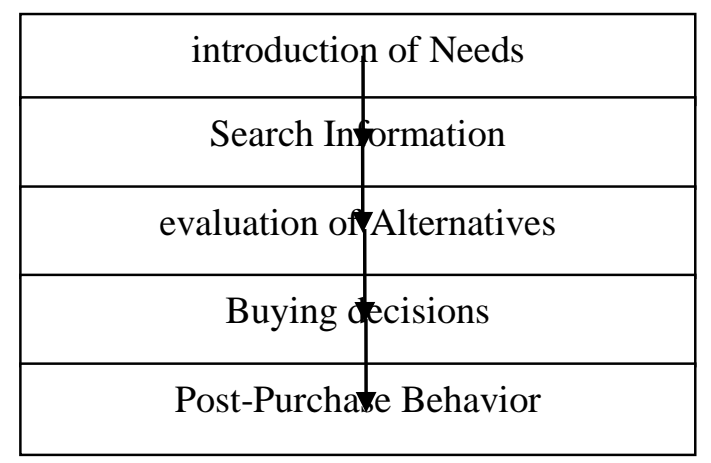

Figure 2: Model of five-stage process to buy

Figure 2 above illustrates that every consumer purchase through five stages. But implementation is often the case in the more routine purchases, consumers often skip or reverse some of this stage. Beginning with the introduction of requirements and then proceed with the purchase decision when consumers recognize their problem or need.

\subsection{Security Level System}

A security issue is one important aspect of an information system. Online transaction security is how to prevent fraud (cheating) or at least did not detect any fraud in an information-based system, where information itself has no physical meaning. Very important value of an information lead to the desired information often can only be accessed by certain people. The fall of the information into the hands of others can cause harm to the owner of the information. For the security of information systems used to be guaranteed within acceptable limits. Security of online transactions continues to dominate discussions on e-commerce [20]. Consumers are concerned about the disclosure of personal and financial information [21]. While most online shopping sites provide privacy information protection policies and security for transactions, they do not offer detailed information about how transactions and personal data is guaranteed [22]. Park and Kim [23] defined security or security as an online store capabilities in controlling and maintaining the security of transactions of data. Furthermore Park and Kim [23] said that security was instrumental in the formation of trust to reduce consumer concern about the misuse of personal data and transaction data that can be easily damaged. When the security level is acceptable and met the expectations of consumers, then consumers may be willing to open their personal information and will purchase with a secure feeling. Raman and Viswanathan [24], through studies conducted on online consumers in Malaysia found that the safety factor has a positive and significant relationship in influencing purchase decisions online. Security is at the core of the majority of Internet transactions. Security is a key factor to the attention of people using the internet to buy, because most transactions are made on the web. According to Deris [25] computer security or also known as cyber security or IT security is the security of the information that is applied to computers and networks. Computer security is aimed at helping the user in order to prevent fraud or detect any attempt of fraud in an information-based system that has a meaning of reality.

Computer security is a branch of technology known as information security as applied to computers. Computer security objectives are among others the protection of information against theft or corruption, or the preservation of availability, as outlined in the security policy. Computer security system is an effort made to secure performance and process computer. Applications of computer security in everyday life are useful as a guard so that system resources are not used, modification, interruption, and plagued by unauthorized 
persons. Security constraints can be identified technical issues, managerial, legal, and political. Computer security will discuss two important things that threats and weaknesses of the system/ vulnerabillity.

Providing computer security requirements against a computer that is different from most system requirements, because they are often in the form of restrictions on what not to do in computer. It makes computer security becomes more challenging because it is quite difficult to create a computer program to do everything what is already designed to be performed correctly. Negative requirements are also difficult to be met and require exhaustive testing for verification, which is not practical for most computer programs. Computer security provides a technical strategy to turn the negative into a positive rule requirement which can be enforced. The general approach taken to improve computer security, among others, is to restrict physical access to the computer, implementing a mechanism on the hardware and operating system for computer security, as well as making programming strategy to produce a reliable computer program. Computer Security is a branch of technology known as information security as applied to computers [25].

Use or benefit of computer security systems that maintain a computer system from being accessed by someone who does not have permission to access the computer system. Computer security systems are increasingly required at this time along with the increasing use of computers throughout the world. Besides the increasing users who connect its LAN networks to the Internet, but not balanced with the human resources to maintain the security of the data and information held. So existing data security is threatened to be accessed by people who are not entitled. Computer security is important because it is associated with:

a. Privacy/Confidentially (secrecy in security standpoint) is to show that none of them get data unless entitled. Confidentiality is usually associated with the data given to the other party for the purposes of particular. Services is intended to keep the messages can not be read by unauthorized parties.

b. Integrity is wholeness with regard to the consistency of the information contained in the existing data on computer networks. Where modification or destruction of data resulted in ignorance of the data generated by malicious code (viruses or worms). To maintain the integrity of the data, the system must have the capability to detect manipulation of messages by unauthorized parties, among others insertion, removal, and replacement of other data into the actual message. So to support this aspect is often used encryption methods (encryption) and digital signature.

c. Presence (Autentication) the authenticity of the services related to identification, both parties identify truth - communicating parties (user authentication or entity authentication), and in identifying the source of the truth of the message (the original data authentication).

d. Available (Availability) this aspect relates to the availability of information when needed. A server that was attacked to death, will make the user can not access the information contained therein.

e. Access Control. This aspect deals with how to control access to information. It is usually associated with authentication and privacy issues.

\subsection{Fraud}

According to Albrecht (2003) [26], Fraud is the act of cheating that is unlawful or illegalacts were intentional and nature could harm others. Another term is fraud such as theft, pilferage, extortion, annexation, embezzlement, etc. Cheating narrowly is a criminal act or acts of corruption. Fraud or cheating itself is an act against the law of the people inside or outside the organization, with the intent to gain personal advantage or group that directly harm others. 
From the definition or understanding of fraud or cheating above, it is illustrated that the definition of cheating or fraud is very broad and can be seen on several categories of fraud. But in general, the elements of fraud (total elements must exist, if there are none then it is considered cheating does not occur) are:

a. There must be one statement (misrepresentation).

b. Of a problem of the past and present.

c. The fact is material.

d. Committed intentionally or without calculation (make - knowingly or recklessly).

The Association of Certified Fraud Examiners (ACFE) [27] or the Association Investigator Fraud Certified, is a professional organization engaged in the examination of fraud in the US has the aim of combating fraud, classify fraud in several classifications, and known as the fraud tree is the classification system on matters posed by cheating the same (Uniform Occuptional fraud Classification System) divides fraud into three types as follows:

a. Asset Missappropriation

Misuse, theft of company property or assets or other parties, this kind of most easy to detect because it is tangiable or can be measured/calculated (defined value).

b. Fraudulent Statement

Actions taken by an officer or executive of a company or government agency to cover the actual financial condition by performing financial engineering (financial engineering) in the presentation of its financial statements to gain an advantage or perhaps analogous to the term window dressing.

c. Corruption

This type of fraud is most difficult to detect because it involves cooperation with other parties such as bribery and corruption, where it is the most common type in developing countries that law enforcement is weak and still lack awareness of good governance so that the integrity factor is still questionable. This type of fraud often can not be detected because the parties to work together to enjoy the benefits (symbiotic mutualism). Including abuse of authority / conflict of interest, bribery, acceptance of unauthorized / illegal (illegal gratuities), and extortion economically (economic extortion). In general, fraud occurs because the underlying three things happening together, namely:

a. Incentive or pressure to commit fraud

b. Opportunities to commit fraud

c. Attitude or rationalization to justify cheating

These three factors are described in the fraud triangle in Figure 3 below:

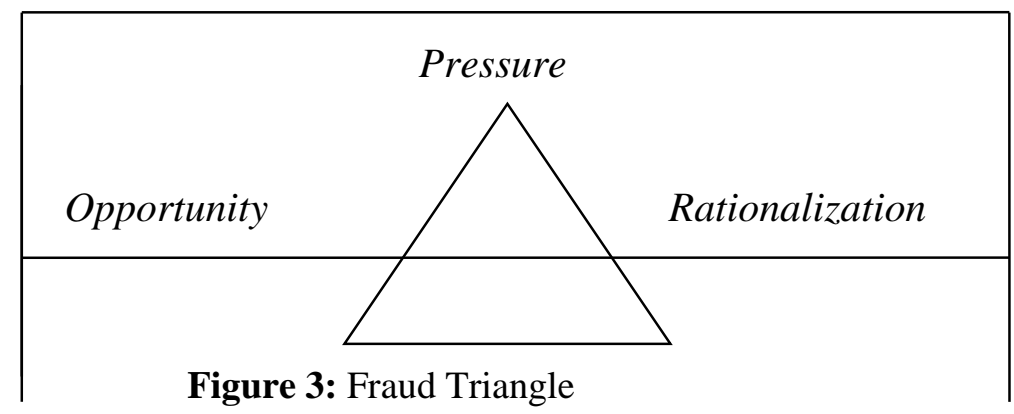


- Opportunity

Opportunity usually arises as a result of weak internal controls in the organization. The opening of this opportunity can also tempt individuals or groups that previously had no motive to commit fraud.

- $\quad$ Pressure

Pressure or motivation of the person or people will make them look for an opportunity to commit fraud, a few examples of pressure may arise from personal financial problems, vices such as gambling, drugs, excessive debt and deadlines and unrealistic work targets.

- Rationalization

Rationalization occurred because someone is looking for justification for activities that contain fraud. In general, the perpetrators of fraud believed or felt that his/her action is not a fraud but is something that is indeed the right, sometimes even perpetrators felt was responsible for doing a lot for the organization. In some cases there is also a condition where the actors are tempted to commit fraud because he felt his colleagues are also doing the same thing and did not receive sanctions for actions such fraud.

\subsection{Cheating in the field of Information Technology, Communications and Multimedia}

Cybercrime has become kind of cheating with the operational entities are already highly dependent on information technology, communications, and multimedia should protect themselves with information control and security right. Cybercrime can occur in the form of attacks from viruses and hackers to the concealment on asset misappropriation and conversion through technological sophistication. Computer technology can be used as a tool offenders computer or cyber crime like the theft of data on a site. Information theft, financial fraud by internet, cybersquatting, carding, hacking, cracking, phishing, and viruses. Cybercrime as the field of computer crime in general can be defined as the use of illegal computer [28]. Cybercrime is used throughout the text to refer to any crime involving computers and networks, including the crime which is not dependent on computer [29].

\subsection{Prevention and Detection of Fraud}

a. Corporate Governance

Conducted by management that are designed in order to eliminate or at least suppress the possibility of fraud. Corporate governance includes corporate culture, policies - policies, and delegation of authority.

b. Transaction Level Control Process

Conducted by the internal auditor, is essentially a process that is more preventive and control aimed at ensuring that only legitimate transactions, authorized adequate noted and protect the company from losses.

c. Retrospective Examination

Directed by the external auditor to detect fraud before they become big and jeopardize the company.

d. Investigation and Remediation

forensic auditor is to determine the action to be taken related to the size and fatality rate of cheating, regardless of whether cheating was only a minor violation of company policy or major violations in the form of fraud in financial reporting or misappropriation of assets.

Fraud prevention could be analogous to the disease, which is better prevented than treated. If waiting for a new fraud handled it means that the existing losses and have been enjoyed by certain parties, compare if we stop him, of course the loss is not all switch to 
the perpetrator of the fraud. And when fraud happens, then the cost is much greater to recover than do prevention early. For prevention, there are at least three attempts to do that:

a. Build individuals in which there is trust and openness, to prevent conflicts of interest, confidential disclosure agreement and corporate security contract.

b. Build a support system of work which includes the integrated system, work standardization, control activities and rewards and recognition system.

c. Building a monitoring system in which there are control self assessment, internal auditors and external auditors.

\subsection{Hypothesis Development. Influence ease of transactions, consumer interest and the security level of partial against fraud measures.}

To test the effect of the ease of the transaction, the consumer interest and the security level of partial to the actions of online shopping fraud, then the hypothesis made is:

$\mathrm{H}_{1}$ : influence the ease of transactions, consumer interest and the security level of partial to the actions of online shopping fraud.

\subsection{Influence ease of transactions, consumer interest and the security level of the system simultaneously against fraud measures}

To test the effect of the ease of the transaction, the consumer interest and the security level of the system simultaneously to the actions of online shopping fraud, then the hypothesis made is:

$\mathrm{H}_{2}$ : influence the ease of transactions, consumer interest and the security level of the system simultaneously to the actions of online shopping fraud.

The main hypothesis formulated above, the framework can be depicted in Figure 4 as following:

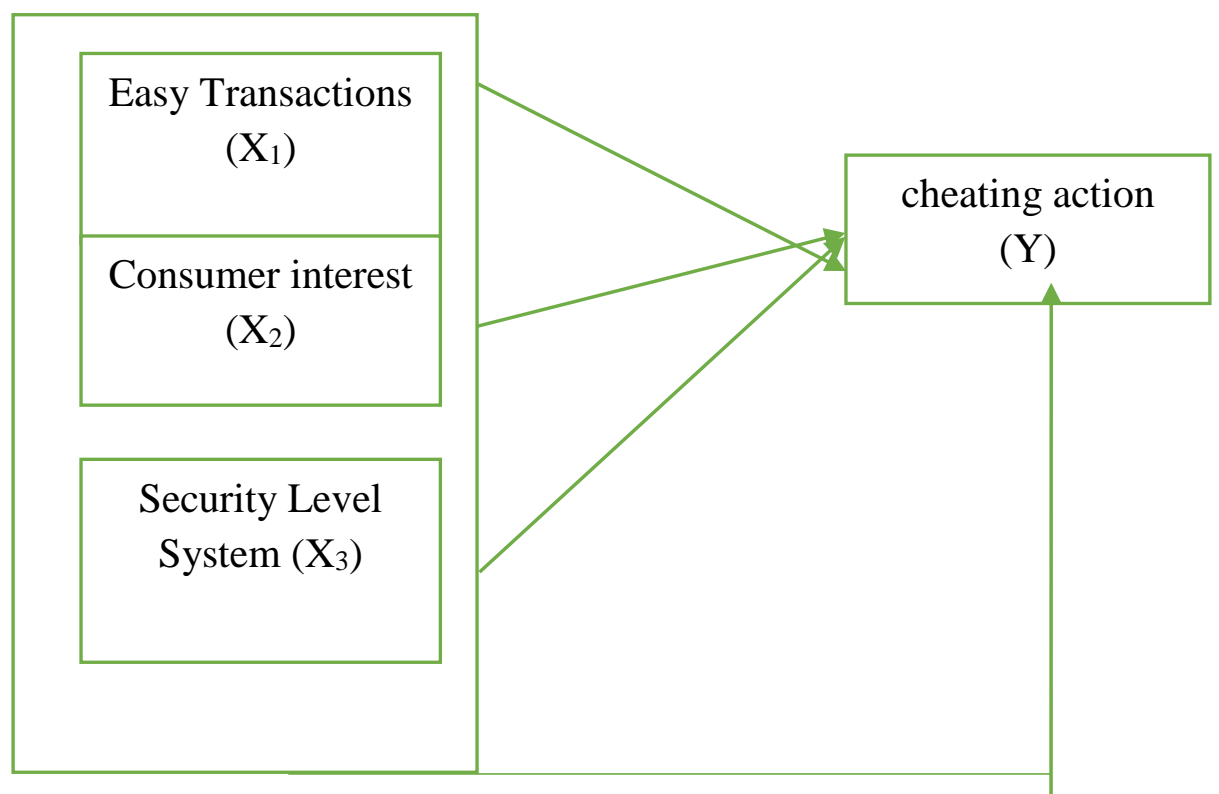

Figure 4: Frame of mind ease of transactions, consumer interest, and the level of system security against online shopping fraud measures 


\section{Material \& Methodology}

\subsection{Research Model and Design}

Model and design of this study was to obtain data on the variables that influence moral thinking and personal factors students. This type of research used in this research is experimental research that used treatment in the form of scenarios in the questionnaire. Source of data used in this study is the data subject, the data in the form of opinions, attitudes, experiences or characteristics of a person or group of people who become subjects of research (respondents). While this type of data in this study is primary data, i.e data obtained directly from the original source.

\subsection{Population}

The population in this study is 2,886 accounting students at Trisakti University, Faculty of Economics in the academic year 2015/2016. The questionnaire that will be distributed to accounting students the first Semesters 1, 3, 5, 7, and 9 of the 100 students in the sample of respondents from the number of accounting students in the academic year $2015 / 2016$.

\subsection{Sampling technique}

The sampling technique is purposive sampling based on the consideration (judgment) is the method of selecting samples with specific goals or targets with particular considerations (Sugiyono, 2010). Consideration accounting student elections in odd semester 1, 3, 5, 7, and 9 Trisakti University Faculty of Economics for students of subscription and experienced on the activities carried out in the deal with online shopping services through the site Lazada.

\subsection{Research Variables and Definitions Research}

There are two variables used in this study:

a. The independent variables used in this study include the ease of transactions measured by the speed of light, high accuracy, high volume transaction, correlated and ease of access to high. Consumer interest as measured by motivation, perception, learning, and memory. And the system's security level as measured by the privacy, integrity, availability, available, and access control.

b. The dependent variable used in this study include acts of fraud as measured by pressure, opportunity and rational.

In this study, there are four operational definition of variables that will be used are:

a. Ease of transaction that is how big the perceived computer technology is relatively easy to understand and use [14].

b. Consumer interest is a behavior of consumers in search of the purchase, use, evaluation, and replacement products and services able to satisfy the needs of consumers [19].

c. Level Security Systems is an information security are applied to computers and networks [25].

d. Action Cheating is an act that is against the law by people from within or outside the organization, with the intent to gain personal advantage or group that directly harm others [26]. 
Tabel 2: Variable Operational Research

\begin{tabular}{|c|l|c|c|}
\hline Variable & \multicolumn{1}{|c|}{ Indicator } & Scale & References \\
\hline \multirow{2}{*}{ Easy } & $>$ Speed of light & & \\
Transaction & $>$ High Accuracy & Likert & Mulyadi (2007) \\
(X1) & $>$ Transaction in large volume & & \\
& $>$ High Connectivity & & \\
& $>$ Easy access & Likert & Kotler (2008) \\
Consumer & $>$ Motivation & & \\
Interest (X2) & $>$ Perception & & \\
& $>$ Mearning & Likert & Deris (2006) \\
& $>$ Privacy & & \\
Security Level & $>$ Integrity & & \\
System (X3) & $>$ Presence & Likailability & W. Steve \\
& $>$ Access control & & Albrecht (2003) \\
\hline \multirow{2}{*}{ Fraud (Y) } & $>$ Pressure & & \\
& $>$ Ottitude & & \\
\end{tabular}

\subsection{Technical Analysis}

The research data will be analyzed using analytical tool of SPSS version 23, which consists of: descriptive staistik, quality test data that test reliability and validity, classical assumptions and hypothesis testing with multiple regression equation (multiple regression) is as follows:

$$
Y=\propto+\beta_{1} X_{1}+\beta_{2} X_{2}+\beta_{3} X_{3}+e
$$

Information:

$$
\begin{array}{ll}
Y & =\text { cheating action } \\
\propto & =\text { constants } \\
\beta & =\text { Slope or Regression Coefficients } \\
X_{1} & =\text { Easy Transactions } \\
X_{2} & =\text { Consumer Interest } \\
\mathrm{X}_{3} & =\text { Security Level System } \\
\mathrm{e} & =\text { Error }
\end{array}
$$

\section{Result and Discussion}

\subsection{Description of Respondents and Variables}

Respondents in this study amounted to 100 consisting of 43 male students (43\%) and 57 women $(57 \%)$. For a respondent age to 18 years as many as 11 students $(11 \%)$, aged 18 years as many as 11 students (11\%), aged 19 years as many as 10 students (10\%), aged 20 years as many as 30 students (30\%), aged 21 years as many as 16 students (16\%), aged 22 years as many as 27 students (27\%), aged 23 years as many as four students (4\%) and 24 years of age by 2 students (2\%). First semester students as many as 25 students (25\%), Third semester students as many as 17 students (17\%), Fifth semester Students as many as 20 students (20\%), Seventh semester student as many as 36 students and ninth semester as many as 2 students. 


\subsection{Quality Test Data}

Test the quality of the data include test reliability and validity test is using SPSS Ver.23. Reliability tests performed by Cronbach Alpha test with Cronbach Alpha values> 0.60 , and test the validity of Correlated item look-Total Correlation. $\mathrm{r}$ table product moment with the 5\% significance. The results of reliability test using Cronbach's Alpha, all measuring devices dependent variable in this study, consisting of variable ease of transactions, consumer interest, and the security level of the system as well as the independent variables consist of acts of fraud have Cronbach's Alpha values greater than 0.60. This indicates that the measuring instrument used in this study is reliable. While the validity of the results of the test showed that all values of $r$ count is greater than the value of $r$ table prodeuct moment at a significance level of 5\% for the N100. Is 0197 so it can be concluded that all items are statements that are used as a measuring tool in this study is valid.

\subsection{Classic Assumption Test}

Tests performed classical assumption in this study is a test for normality by using analysis graphs (Normal Probability Plot) and test kolmogorov semirnov against entirely dependent variable is normally distributed. The test results multicoloniarity the independent variable tolerance value indicating no independent variables that have a tolerance of less than 0.10 (VIF under 10), which means there is no correlation between the independent variable whose value is more than $95 \%$ or all independent variables no multicoloniarity. While the results of the Kolmogorov Smirnov test heterokedastisitas indicate significance probability values above the 5\% confidence level or, correlation significance value greater than 0.05 which means it can be inferred that the regression model used do not contain heteroskedastisitas. The test results heterokedasitas using graph analysis Scatter Plott is known that there is no clear pattern, and dots spread randomly and spread both above and below the number 0 on the $\mathrm{Y}$ axis, it can be concluded that there is no heterokedastisitas the regression model, so the model regression declared eligible for use.

\subsection{Discussion Hypothesis. Ease of Online Shopping Transaction influence Measures Against Fraud Online Shopping}

The results of the analysis proved that the ease of online shopping transactions Lazada in Jakarta did not affect positively and significantly related to acts of fraud despite the factors ease of transaction, as measured by the ease of access to high significant effect on the action of cheating due to demonstrate the ease of access to the high conducted in the presence of a virtual marketplace or the market place without having to meet the seller and buyer are accessed virtually wherever they are supported by the flexibility provided will not experience limitations or limitations to market access. In addition a range is not limited by time and place so that lower transaction costs both producers and consumers can save costs. The result can provide opportunities for action cheating. In addition to the ease of transaction variables that measured the speed of light does not significantly influence the action of fraud. This is due to the speed of light is able to experience the competition base expansion driven by increasing capacity and quality to environmental changes and immediately follow up with a quick and formulated comprehensive. Making it possible to not commit acts of fraud given the extent of the competition basis.

The analysis of the ease of transaction variables measured with high accuracy does not significantly influence the action of fraud. This is because there are statutes and reliability in providing services which can prevent the occurrence of errors because it is supported by improving its ability in learning with a better understanding and exchange of information or experience with other companies. So that high accuracy is less to prevent 
acts of fraud. The analysis of the variables measured by the ease of transactions that high volume transaction does not significantly influence the action of fraud. It shows that the high volume transaction tremendous impact on increasing productivity, which is no longer limited volume of transactions physically. Consequently able to serve consumers in large quantities in the same period of time to build and maintain relationships with consumers, and offer goods and services. So less to do acts of fraud. The analysis of the variables measured by the ease of transactions highly correlated no significant effect on the action of fraud. It shows a high connectedness can rapidly conduct transactions globally simultaneously or together. Consequently Supported by monitoring access to the site (website), facilitates organizations to constantly keep abreast of the latest environment. So the possibility of continuous connectivity allows avoid the occurrence of acts of fraud.

\subsection{Consumer interest influence Measures Against Fraud Online Shopping}

The results of the analysis proved that consumer interest in online shopping Lazada in Jakarta did not affect positively and significantly related to acts of fraud even though the factors of consumer interest as measured by the motivation to have a significant effect on the actions of fraud, due to the requirement that the motive when the need was increased to the level of intensity sufficient to encourage a person to act as expected for a product in a short time and does not require more power to buy. The result can be taken cheating to attract the level of intensity of the individual to push to buy products or services desired contrast with that offered compared by three sub variables consumer interest as measured by perception, learning, and memory in the variable does not affect the level of action fraud significantly.

In addition to the variables measured by the consumer interest does not significantly influence the perception of fraud action. This shows that perception is a process to select, organize, and interpret information in the can so as to create a good picture online shopping so interested in doing online shopping transactions. In addition there are individuals or groups who are not interested in buying just enjoying being offered by online shopping sites. Thereby reducing the occurrence of acts of fraud. The analysis of the variables measured consumer interest by learning no significant effect on the action of fraud. It shows that the study gives a good effect. With their learning activities to encourage someone to repeat or not on information that personally experienced or heard so little incentive to shop online interest for the ministry received satisfactory or just went along with friends or other factors. However, as experience provides many positive comments, satisfying consumers thus lowering action of fraud. The analysis of consumer interest variables measured by the memory does not significantly influence the action of fraud. This means memory storage with short-term or long-term will give a person experiences, images, thoughts, attitudes, beliefs and feelings to shop online with a keen memory of being owned by each individual. So it can help in reducing the chances of fraud action.

\subsection{Effect of Online Shopping System Security Measures Against Fraud Online Shopping}

The results of the analysis proved that the system security level affect positively and significantly related to acts of fraud despite the factor systems security level as measured by integrity do not have a significant effect on the actions of fraud caused that the consistency of information on existing data on the computer network suffered the destruction of data resulting data can not be read by a virus or worm so that the system should have the ability to detect manipulation with insertion, removal and replacement of the usual methods used by the encryption method and digital signature. Consequently can prevent the occurrence of acts of fraud, but the other sub variables measured with privacy, 
availability, and access control significantly influence the actions of fraud. In addition the system's security level variables measured by privacy significantly influence the action of fraud. This is because of confidentiality in the information security point of view by the party entitled or in accordance with the authority. So that it can provide an opportunity to commit fraud action if information is used by the parties are not entitled.

The analysis of the variable system's security level as measured by the existence of a significant effect on the action of fraud. This is due to provide services authenticity and veracity of the information related to identifying the parties to communicate with each other or identify the source of the information they provide in accordance truth. The result can provide opportunities for fraud action if these parties provide resources that are not true. The analysis of the variable system's security level as measured by available significant effect on the action of fraud. This is because the information received and obtained readily available to users either internal or external parties, if the server is manipulated then the user can not access or an error occurred in the provision of necessary information. The result can be difficult to commit acts of fraud. The analysis of the variable system's security level as measured by the access control significant effect on the action of fraud. This is because the information is stored either received or acquired from external parties or in discount arrangements to be able to access that information with the privacy and availability of data. As a result, the parties who are not interested can not access the required information because it already has an access code to be able to use such information for action so that less cheating. This study is in line with the research in [30], that partially found that security variable positive and significant effect on purchasing decisions.

\subsection{Ease Effect of the Transaction, consumer interests, and Systems Security Levels Simultaneously Measures Against Fraud Online Shopping}

The influence of ease transactions, consumer interest, and the security level of the system simultaneously against acts of fraud positive and significant effect on the action of cheating on online shopping Lazada in Jakarta despite the factors acts of fraud as measured by transactions in large volume, highly correlated, integrity and learning does not have a significant effect on the action of cheating but to ten sub variables measured by the ease of access to high speed of light, high accuracy, perception, motivation, memory, privacy, availability, available and access control together to influence the actions of fraud significantly.

This is due to the ease of access to the high conducted in the presence of a virtual marketplace or market place without having to meet the seller and buyer are accessed virtually wherever they are supported by the flexibility provided will not experience limitations or limitations to market access. In addition a range is not limited by time and place so that lower transaction costs both producers and consumers can save costs. The result can provide opportunities for action fraud. Meanwhile, because of the needs that have been the motive when it needs to rise to the level of intensity that is enough to encourage someone to act as expected for a product in a short time and does not require more power to buy them. As a result of fraud actions can be done by pulling the intensity level of an individual in order to encourage to buy products or services desired contrast with that offered.

This study is in line with the research in [30] that simultaneously which found that the variable quality of service is positive and significant impact on consumer decision making purchases online despite the differences that do not have sub-variables together can significantly influence the acts of fraud. The study was also supported by Firman [7] who found that the quality of service is positive and significant effect on the level of online shopping patterns. 


\section{Conclusion}

The ease of online shopping transactions Lazada in Jakarta is not positive and significant effect on the action of cheating though factors ease of transaction, as measured by the ease of access that is high has a significant effect on the action of cheating showed the ease of access to the high conducted in the presence of a virtual marketplace or market place without having face to face between the seller and the buyer are accessed virtually wherever they are supported by the flexibility provided will not experience limitations or limitations to market access. In addition a range is not limited by time and place so that lower transaction costs both producers and consumers can save costs. The result can provide opportunities for action fraud. Consumer interest in online shopping Lazada in Jakarta is not positive and significant effect on the action of cheating though factors act of cheating as measured by motivation, have a significant effect on the actions of fraud, this was due to the need rise to the level of intensity that is enough to encourage a person to act in accordance the desirable for a product in a short time and does not require more power to buy them. As a result of fraud actions can be done by pulling the intensity level of an individual in order to encourage to buy products or services desired contrast with that offered.

System security level proves that the security level of online shopping system Lazada in Jakarta positive and significant effect on the action of cheating though factors of security levels measured with integrity does not have a significant effect on the action of cheating, consistency of information on existing data on computer networks encounter destruction of data resulting data can not be read by a virus or worm so that the system should have the ability to detect manipulation by the insertion, deletion and pensubsitusian methods commonly used by the encryption method and digital signature. Consequently it can prevent the occurrence of acts of fraud.

Ease of transactions, consumer interest, and the security level of positive and significant effect on the action of cheating on online shopping Lazada in Jakarta despite the factors acts of fraud as measured by transactions in large volume, highly correlated, integrity and learning does not have a significant effect on fraud measures yet to nine sub variables measured with high ease of access, the speed of light, high accuracy, perception, motivation, memory, privacy, availability, available, access control together significantly influence the actions of fraud.

\section{Acknowledgement}

This research is supported by Universitas Prof. Dr. Moestopo (Beragama), Indonesia. The authors would like to that Dyan Safirawati in finalizing this manuscript.

\section{References}

[1] Hermawan, K. Positioning, Diferensiasi, dan Brand. Jakarta: PT. Gramedia Pustaka Utama, 2004.

[2] Wells, J.D.,Valacich, J.S.; and Hess, T.J. What Signals Are You Sending? How Website Quality Influences Perceptions of Product Quality and Purchase Intentions, MIS Quarterly, 35(2), 373-396, 2011.

[3] Hsu, M-.H. and Chiu C.-M. Internet Self Efficacy and electronic service acceptance. Decision Support System, 38(3), 369-381, 2004.

[4] Supriyanto, A. Pengantar Teknologi Informasi. Salemba Empat, Jakarta, 2005.

[5] O'Brien, J.A. Introduction to Information System: Essentials for theEbusiness Enterprise, $11^{\text {th }}$ edition. McGraw Hill Inc, New York2003.

[6] Romney, M.B., \& Steinbart, P.J. Accounting Information Systems, $10^{\text {th }}$ edition. Pearson Prentice Hall, New Jersey, 2006.

[7] Firman, A.K. Analisis Faktor - Faktor yang Mempengaruhi Motif Belanja Online pada Lejel Home Shopping di Makassar. Unpublished Undergraduate Thesis, Faculty of Economics and Business, Universitas Hasanuddin Makassar, 2014. 
[8] Suhartini. Analisis Faktor Faktor yang Mempengaruhi Motif Belanja Secara Online di Komunitas Kaskus Semarang. Semarang; Technical report, Faculty of Economics and Business, Universitas Diponegoro Semarang, 2011.

[9] Ollie. Membuat toko online dengan multiply. Jakarta: Media kita, 2008

[10] O'Brien, J.A., Marakas, G.M. Management Information System. McGraw-Hill Inc, New York, 2006.

[11] O'Brien, J.A. Pengantar Sistem Informasi: Persefektif Bisnis dan Manajerial $12^{\text {th }}$ edition. Salemba edition. Salemba Empat, Jakarta, 2005.

[12] Solomon, M.R. \& Rabolt, N. Consumer Behavior in Fashion, $2^{\text {nd }}$ Edition. USA: Prentice Hall, 2009.

[13] Davis, F.D. Perceived Usefulness, Perceived Ease of Use and User Acceptance of Information Technology. MIS Quarterly, 13(3), 319-340, 1989.

[14] Chin, W.W., \& Todd, P. On The use Usefullness, ease of use of structural equation modeling in MIS Research: A note of Caution. MIS Quarterly, 19(2), 237-246, 1995.

[15] Mulyadi. Sistem Perencanaan dan Pengendalian Manajemen. Universitas Gadjah Mada. Salemba Empat, Edisi 3, 2007.

[16] Adams, D.A., Ryan N., \& Peter A.T. Percieved usefulness, ease of use, and usage of information technology: A replication. MIS Quarterly, 16, 227-250, 1992.

[17] Igbraria, M., \& Chakrabarti, A. Computer Anxiety and Attitudes TowardsMicrocomputer Use. Behaviour Inform. Tech. 9(3) 229-241, 2000.

[18] Jogiyanto. Sistem Informasi Keperilakuan. Yogyakarta: Andi Yogyakarta, 2007.

[19] Kotler, P. Manajemen Pemasaran, Edisi 13 Jilid 1, Jakarta: Erlangga, 2008.

[20] Elliot, S., \& Fowel, S. Expectations versus reality: A Snapshot of Consumer experiences with internet retailing. International Journal of Information Management, 20, 323-336, 2000.

[21] Maholtra, N. K., Kim, S. S., \& Agarwal, J. Internet users' information privacy concern (IUIPC). The construct the scale, and a causal model. Information System Research, 15 (4), 336-355, 2004.

[22] Gauzente, C. Web merchant's privacy and security statement: How reassuring are they customers? Two sided approach, Journal of Electronic Commerce Research, 5(3), 181-198, 2004.

[23] Park, C.H., \& Kim Y.-G. The effect of information satisfaction and relational benefit on consumers' online shopping site commitments. Journal of Electronic Commerce in Organizations (4), 70-90, 2006.

[24] Raman, Arasu., \& Viswanathan, A. (2011). "Web Services and e-Shopping Decisions: A Study on Malaysian e-Consumer". IJCA Special Issue on:Wireless Information Networks \& Business Information System, hal.54-60.

[25] Stiawan, Deris. 2005. Sistem Keamanan Komputer. Jakarta. PT Elex Media.

[26] Albercht, W.Steve dan Chad O. Albercht. 2003. Fraud Examination. Ohio : South Western.

[27] ACFE. 2010. Fraud Examiners Manual, 2010 ed, Austin, Texas.

[28] Andi Hamzah, 1989. Aspek-aspek Pidana di Bidang Komputer, Jakarta: Ghalia Indonesia.

[29] Eoghan Casey, Digital Evidence and Komputer Crime, (London : A Harcourt Science and Technology Company, 2001.

[30] Andriyani, Dewi; Soengkono, Soengkono. 2014. Pengaruh Faktor Keamanan, Pengetahuan Teknologi Internet, Kualitas Layanan dan Persepsi Resiko terhadap Keputusan Pembelian melalui Situs Jejaring Sosial. Unpublished Undergraduate Thesis, Faculty of Economics and Business, Universitas Bengkulu.

[31] Hoga, S. dan Rizky, R. Pengaruh Intensi Pelanggan Dalam Berbelaja Online Kembali Melalui Media Teknologi Informasi Jual Beli (FJB) Kaskus, Journal of Information System, 8(2), 100-112, 2012.

[32] Adi, R.N., \& Widiyanto, I. Analisis Faktor -Faktor yang Mempengaruhi Keputusan Pembelian dengan Sistem Pre Order secara Online (Studi Kasus Pada Online Shop Chopper Jersey). Unpublished Undergraduate Thesis, Faculty of Economics and Business, Universitas Diponegoro, 2013.

[33] Bento Adityo. Analisis Pengaruh Kepercayaan, Kemudahan, dan Kualitas Informasi Terhadap Keputusan Pembelian Secara Online Di Situs Kaskus. Unpublished Undergraduate Thesis, Faculty of Economics and Business, Univesitas Diponegoro, 2012.

[34] Sugiyono. Metode Penelitian Kuantitatif Kualitatif dan R \& D. Bandung. Alfabeta, 2010.

[35] Agung N. Strategi Jitu memilih Metode Statistic Penelitian dengan SPSS, Yogyakarta: Andi, 2005.

[36] C, Trihendradi. 2011. Langkah mudah melakukan analisis statistik menggunakan SPSS 19. Yogyakarta: Andi.

[37] Ghozali, I. 2006. Analisis Multivariate Lanjutan Dengan SPSS .Edisi I.Semarang: BP UNDIP.

[38] Duwi P. 2010. Teknik Mudah dan Cepat melakukan analisis Data Penelitian dengan SPSS. Yogyakarta: Gava Media.

[39] Priantara, Diaz. 2013. Fraud Auditing and Investigation. Jakarta: Mitra Wacana Media.

[40] Alison. 2004. Fraud Auditing. The Audit Journal. 